Neuro/mages
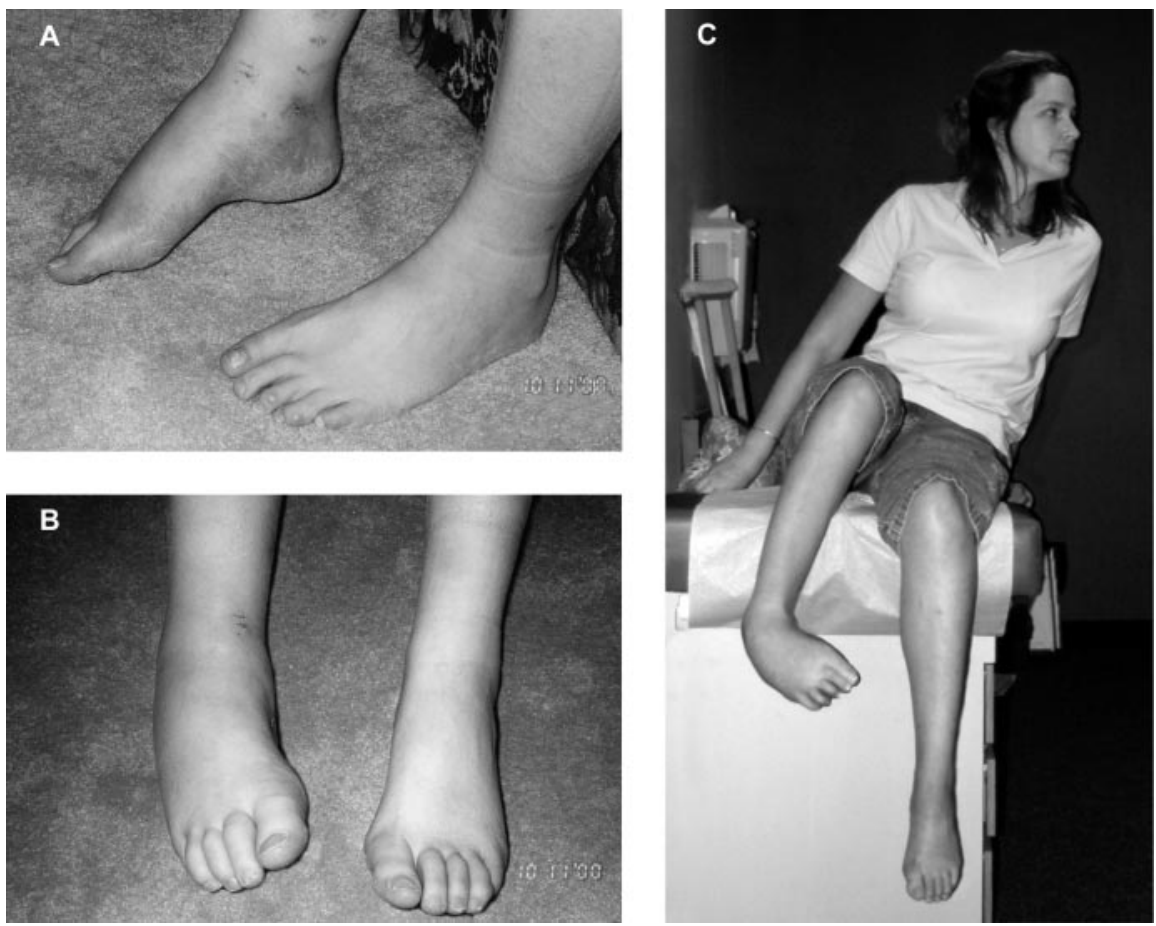

Figure. Photographs taken 1 month after the inciting vascular surgery demonstrate healing without infection (A), but swelling and mild varus deviation of the right foot $(B)$, indicative of early autonomic and motor signs of complex regional pain syndrome. At 3 years postoperatively, her dystonia is severe and disabling $(C)$, necessitating crutches for walking. A video depicting this patient's accompanying bilateral tremor accompanies this case (see video clip 1 on the Neurology Web site).

\section{VIDEO Progression of dystonia in complex regional pain syndrome}

Anne Louise Oaklander, $M D, P h D$, Boston, $M A$

A healthy woman aged 35 years underwent uneventful stripping of a varicose right saphenous vein. Severe right lower-leg pain and muscle spasms appeared immediately postoperatively. Reflex sympathetic dystrophy was diagnosed 7 weeks postoperatively. ${ }^{1}$ Electrophysiologic study 9 weeks postoperatively demon-

Additional material related to this article can be found on the Neurology Web site. Go to www.neurology.org and scroll down the Table of Contents for the July 27 issue to find the title link for this article.

Address correspondence and reprint requests to Dr. Anne Louise Oaklander, Massachusetts General Hospital, 55 Fruit Street, Clinics 3, Boston, MA 02114; e-mail: aoaklander@partners.org strated unobtainable sural responses and gastrocnemius denervation on the right. Lumbosacral MRI revealed no abnormalities. Serial radiologic examinations documented progressive right-foot osteopenia. Her dystonia worsened and spread proximally, affecting her lumbosacral spine; tremor developed in the contralateral foot. These serial photographs (figure) illustrate progression of the dystonia that is increasingly recognized as part of complex regional pain syndrome (CRPS), particularly in patients with HLA-DR13 (see video clip 1 on the Neurology Web site at www.neurology.org). ${ }^{2}$ The case demonstrates that motor dysfunction in CRPS can begin immediately after the causative event, supporting other evidence that neither disuse nor psychological factors are primary causes.

1. Schwartzman RJ, Kerrigan J. The movement disorder of reflex sympathetic dystrophy. Neurology 1990;40:57-61.

2. van Hilten JJ, van de Beek WJ, Roep BO. Multifocal or generalized tonic dystonia of complex regional pain syndrome: a distinct clinical entity associated with HLA-DR13. Ann Neurol 2000;48:113-116. 


\section{Neurology}

\section{Progression of dystonia in complex regional pain syndrome \\ Anne Louise Oaklander \\ Neurology 2004;63;751 \\ DOI 10.1212/01.WNL.0000130515.60724.02}

This information is current as of August 23, 2004

\section{Updated Information \& Services}

Supplementary Material

References

Citations

Subspecialty Collections

\section{Permissions \& Licensing}

Reprints including high resolution figures, can be found at: http://n.neurology.org/content/63/4/751.full

Supplementary material can be found at: http://n.neurology.org/content/suppl/2004/08/09/63.4.751.DC1

This article cites 2 articles, 1 of which you can access for free at: http://n.neurology.org/content/63/4/751.full\#ref-list-1

This article has been cited by 1 HighWire-hosted articles: http://n.neurology.org/content/63/4/751.full\#\#otherarticles

This article, along with others on similar topics, appears in the following collection(s):

\section{All Clinical Neurology}

http://n.neurology.org/cgi/collection/all_clinical_neurology

All Pain

http://n.neurology.org/cgi/collection/all_pain

Dystonia

http://n.neurology.org/cgi/collection/dystonia

Tremor

http://n.neurology.org/cgi/collection/tremor

Information about reproducing this article in parts (figures,tables) or in its entirety can be found online at:

http://www.neurology.org/about/about_the_journal\#permissions

Information about ordering reprints can be found online:

http://n.neurology.org/subscribers/advertise

Neurology ${ }^{\circledR}$ is the official journal of the American Academy of Neurology. Published continuously since 1951, it is now a weekly with 48 issues per year. Copyright . All rights reserved. Print ISSN: 0028-3878. Online ISSN: 1526-632X.

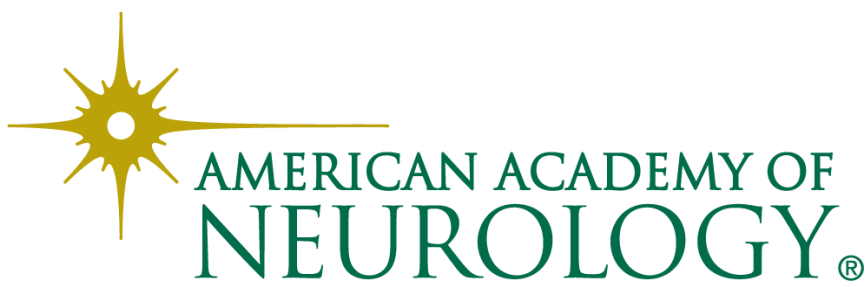

